12時間および1日に藷明な減少が億められた。

(2) ラット：暴露12時間上り鼠腔前部の睤甲介烀吸上皮 に上皮内細胞浸潤，空胞化，上皮の一部脱落，固有摆内 白血球浸潤等方柽度にみられた。これらの病変は1日， 2日，3日上もほぼ同じで，5日目には上記病変が最も 著明となり，舅腔一の浸溜・脱落細胞数も増加した。

(3)マウス：3日までは特に桨化がみられたかっったが， 5 日目には嚳腔前および中部の率甲介，上・中外側壁の 呼吸上皮の稩胞浸潤，固有層内の白血球の增数扝よび鼻 腔内の整度細胞浸潤がみられた。

レずれの動物でも，暴露により出現した病変は，終了 3 日後には対照群とほぼ同じに修復されていた。

結 論

5 日間の $\mathrm{NO}_{2}$ 暴露に拈いて, 死亡率, 体重の変化, 肺湿重暴括上び病理組織学的㮩查の結果加b, golden一 ムスターは，Wistar ラットおよび ICR マウスに比心゙ て明らかに感受性が高かった。
鼻粘膜の病理変化は，八ムスターては暴露12時間抢上 び1日に顥著に観察され，暴露中にもかかわらず，2日 以降で经病変の怪減が認められた。ラットおよびマウス では初期の病変は軽度かほと儿ど認められず，5日閒暴 露終了直後にかなり強い病変が認められた。

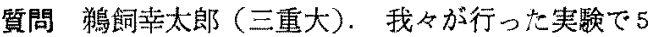
$\sim 10 \mathrm{ppmSO}_{2}$ の暴露により粘液線毛速度が荤延に続く䒕 進を示古所見を婗察しているが，この所見上本日発表の 病变の俥減七相関があるよらに考えるが，そのメカニズ ムについて。賢問 海野徳二(旭川医大)。動物間 の差を生じているのは，何が一番可能性があると考えて いるか。応答 形態的には修復像を認めているが， 生理学的には覞察しいない.今後検討したい。応答 非常にむすかしい問題であるが，形偟学的には特に差を 認めていないので, 生化学的, 生理学的追求が必要と思 5 .

(B 82-1207--32010)

\title{
224. 七ト鼻粘膜上皮繊毛の脱落について
}

\author{
○大木稔文・増田官太郎・園浦利雄・坂部長正 (中央鉄道病院)
}

ヒト鼻粘膜上皮緎毛の形成，形態の微細構造について 観察しているらちに, 慢性気道炎などの際に繊毛の脱落 (deciliation) がみられることがある. deciliation の状

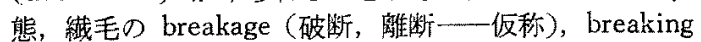
point について微細棈造を示説し，その形成に関して推 論した。

材料と方法 慢性気道炎, 副鼻腔炎患者の外来および 手術時で，また剖検時の新生児の鼻粘膜上皮(下畕甲介 前下部粘膜文主体として）を採取，細切して，カコジル 酸緩衝 (pH 7.4) 2.5\% glutaraldehyde で 1 時間半一 2 時間水室で固定し, 次いで $8 \%$ \%割合で sucrose を加 えた同緩衝液で洗い，2\% $\mathrm{OsO}_{4}(\mathrm{pH} 7.4) 2$ 時間の二 重固定した。 アセトン系列脱水後, Epon 812 で包埋し た. Reichert OmU2 型マイクロトームにガラスナイフ を装用して, 約 $60 \mathrm{~nm}$ 以下の厚さの超薄切片をコロシ オン膜付の銅板メッシ二上に载せ，乾燥，醋酸ウラニル 上クエン酸鉛の三重染色を行って，日本電子製 JEM $100 \mathrm{U}$ 透過型電子顥微鏡 $(80 \mathrm{kV})$ で短察撮影して検討 した.

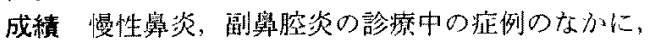
特に萎縮性，臭鼻症で䋐毛の脱落 (deciliation) の像が みられたものがある。なかには breakage 像も諗められ る. 移行部でみられ，中心細䋊維(小管，微小管）形成付近 で基底環付近 terminal region, terminal zone である. 初めに周辺双細䋐濰（小管，微小管）加破断されて，dot がみられ，さらに雄断する、瀻毛膜の breakage, 㵶毛 幹の脱落が生しる像を経㭙的に示説した。. また異常織毛
にも breakage がみられる像を示した。

慢性気道炎のなかに慢性肥厚性鼻㷋の一部には絬膜上 皮化生しているものむあるが，緎維細胞が残存してい て, 繊毛の脱落の像むかなりみられる。

絨毛㲦の breakage による瀻毛の脱落ではいすれれも基 底体のみは残存しているが，やがては基底体も崩壊する と推論した。

繊毛の脱落 (deciliation) を生ずる breakage, breaking point につけては医学上の文献にまとまった詳細 な記戴はみられない，原生動物の繊毛に関する breakage について, J.J. Blum らは terminal region であるとの ヘてている、私達はこの説に賛成である、他の説もある が.

breakage が生ずる微小管破壊について R.D. Berlin らはコルヒチンなどの抗微小管剤に関して，またD. Papahadjopoulos 5 が比較的高濃度 $\left(2 \times 10^{-8} \mathrm{M}\right)$ の ブカイン，テトラカインなどの局所麻醉薬によって細胞 翼の微小管招よびミタロフィラント采の崩壊がなされ， 微小管ネットワークを脱組織化させるといわれている. しかし微小管だけに作用する菒物は現在まだ分っていな いので，臨床上で緎毛脱落の機序およびその予防につい ては今後に残された問題であるとのべた。

質問 安原晴三（蔺山地方会）、上皮緎毛の脱落又は それに近い状態時の鼾腔萎縮・乾燥感に対しての予防・

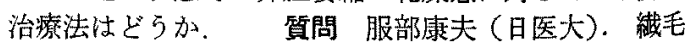
の脱落は，㵶毛細胞の変性・脱落に伴5所見なのか, 細 胞自体と関保のない瀻毛のみの所見なのか。質問 海野德二（地川医大），瀻毛の脱落があった時にその細 
胞の繊毛の再生についてはどのようになるか、質問 奥田稔 (日本医大). 繊毛の脱落は生理的現象か病 的現象か. 応答 臨床とただちに密接しての結論は だし難、。応答 慢性炎症の鼻粘膜上皮には繊毛細 胞の脱落はかなり認められる。本日は1本の繊毛の脱落
についてのみのべた。応答 繊毛脱落後の再生につ いては不明. 応答 新生児の例にも少しは認められ る. 慢性炎症の症例, 特に萎縮性鼻炎, 臭鼻症の症例に は多いので病態と思う。

( B $82-1208-32110)$

\title{
225. 鼻・副鼻腔 papilloma の超微形態的観察
}

\author{
○服部康夫 - 弓削庫太 - 中村 賢 - 村上忠也 - 児玉駿一郎 - \\ 物集女誠治（日医大）
}

鼻, 副鼻腔 papilloma は比較的稀な良性腫瘍である が, 外科的治療を行っても再発することが多く, 時には 癌化あるいは癌と共存することが指摘され, 前癌状態と して取扱らことを提唱寸る報告が多く，臨床的にも，病 理組織学的にも興味ある疾患の一つといえる.

本腫瘍は, 病理 組織学的に, 腫瘍細胞の増生形態 (Norris 1963) と腫瘍構成細胞 (Tobeck 1929) によっ て分類されることが多い。

我々は, 最近 2 年間に経験した exophytic papilloma 2 例, inverted papilloma 2 例及び両方の傾向を示した 1 例の 5 症例の鼻. 副鼻腔 papilloma を, 透過電顕並 びに走査電顕的に観察し得たので，その成績について報 告する.

今回は，腫瘍細胞と間質との関係（特に基底膜につい て), 腫瘍細胞の増殖と分化及び腫瘍の表層細胞などに ついて述べた.

1. 基底膜について

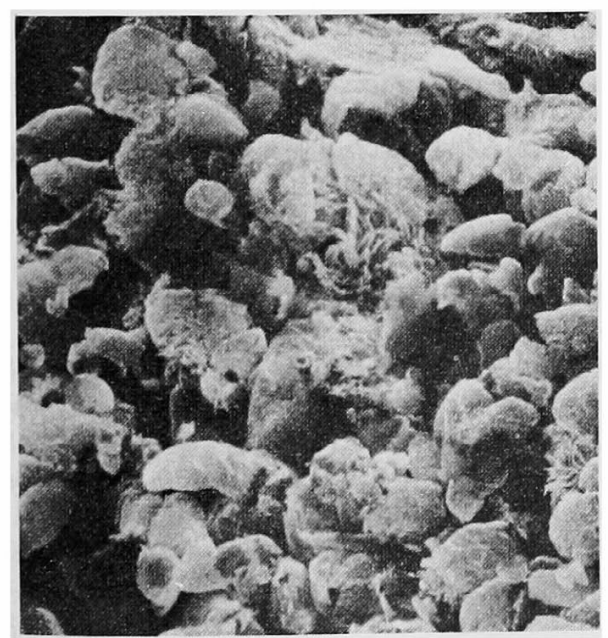

写真 1 inverted papilloma で円柱上皮より なる。一部に線毛細胞をみるが他の細胞 は変性が著明である。( $(\times 1000)$ exophytic papilloma の基底膜は，平坦あるいはゆる やかな波状に細胞膜と平行して走行し，基底膜の断裂は 稀にしかみられなかった. inverted papilloma では，基 底膜は平坦, ゆるやかな波状あるいは䊂波状に走行し, 細胞膜と基底膜が平行しないことあるいは基底膜の断裂 をみることが有り，その断裂部より細胞質突起あるいは 腫瘍細胞そのものが間質に向って突出していることがあ った.

この基底膜の断裂及びその部よりの細胞質あるいは腫 瘍細胞の突出は, 増殖力の増大した再生上皮, 癌細胞に しばしばみられる所見で, inverted papillomaにおい ても基底部の細胞の増殖力が増し, 細胞の運動性が六進 していることを示すものと推定される。

2. 腫瘍細胞の増殖について

5 症例ともに細胞分裂像を豊富に認めた，基底膜に接 する基底細胞様細胞に認めることが多かったが，基底膜 より $2 \sim 3$ 層, 時には $4 \sim 5$ 層上位の細胞にも分裂像を

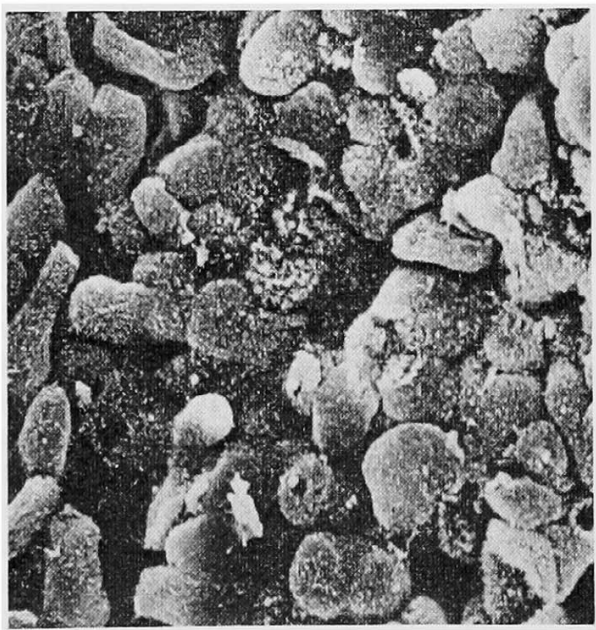

写真 2 inverted papilloma で移行上皮より なる、一部に microvilli の多い細胞をみ る. 他の一部には角化傾向を示寸細胞を 認める. $(\times 1000)$ 